Biol. Neonate 1983;43:I-IV

\title{
Contents, Vol. 43, 1983
}

No. 1-2 Editorial Notes I

Acknowledgement Ill

Sites of Action of Light during Phototherapy

Granati, B.; Felice, M.; Fortunato, A.; Giancola, G.; Rubaltelli, F.F 1

Respiratory Distress Syndrome in the Newborn: Relationship to Serum Prolactin, Thyroxine, and Sex

Dhanireddy, R.; Smith, Y.F.; Hamosh, M.; Mullon, D.K.; Scanlon, J.W.; Hamosh, P. 9

Cerebrospinal Fluid Concentration of Biogenic Amine Metabolites in Idiopathic Apnea of Prematurity

Bhat, A.M.; Scanlon, J.W.; Lavenstein, B.; Chuang, L.; Karoum, F 16

Developmental Pattern, Tissue Distribution, and Subcellular Distribution of Cysteine: $\alpha$ Ketoglutarate Aminotransferase and 3-Mercaptopyruvate Sulfurtransferase Activities in the Rat

Kuo, S.-M.; Lea, T.C.; Stipanuk, M.H

Effects of Maternal Diabetes on the Development of Carbohydrate-Metabolizing Enzymes, Glycogen Deposition and Surface Active Phospholipid Levels in Fetal Rat Lung

Singh, M.; Feigelson, M 33

Developmental Changes in Fetal Adrenal Hypertrophy following Maternal Bilateral and Fetal Unilateral Adrenalectomy at Different Stages of Gestation in the Rat

Yamamoto, M.; Eguchi, Y.; Asari, M.; Kano, Y

Cardiovascular Effects of Dopamine in Developing Swine

Buckley, N.M.; Brazeau, P.; Frasier, I.D 50

Effects of Acute Preload and Afterload Stress on Myocardial Function in Newborn and Adult Sheep

Berman, W.; Christensen, D 61

Patterns of Monoamine Oxidase Maturation in Mouse Brain

Baker, P.C.; Hoff, K.M.; Samsa, J.M 67

Effects of Excess Amounts of Synthetic Amino Acid Preparations on Hypothalamus of Mice and Kittens

Tanaka, K.; Shimada, M.; Nakao, K.; Kosugi, A.; Yamamoto, H.; Oya, N 72

Prenatal Development of Brown Adipose Tissue in Man. A Morphometric and Biomathematical Study

Moragas, A.; Torán, $\mathrm{N}$ 80

Nitrogen Metabolism in the Sheep Fetus. Observations on the Liver and Placenta

Rubio, V.; Tan, C.B.; Andrews, W.H.H. †; Nixon, D.A. †; Alexander, D.P.; Britton, H.G. 86 Morphological Changes in Lipid Droplets Within Cells of the Duodenal Transition Zone in Suckling Rats

Berendsen, P.B.; Blanchette-Mackie, E.J 92

Evidence that Medium-Chain Fatty Acid Oxidation Can Support an Active Gluconeogenesis 
in the Suckling Newborn Rat

Turlan, P.; Ferre, P.; Girard, J.R

Contents

III

No. 3-4 Inhibition of Lymphocyte Transformation by Serum from Pregnant Women: Lack of

Correlation with Levels of Alpha-Fetoprotein

Papiha, S.S.; Wajner, M; Wagstaff, T.I 109

cti-Acid Glycoprotein in the Neonate with and without Infection

Philip, A.G.S.; Hewitt, J.R 118

Functional Residual Capacity and Sleep States in the Premature Newborn

Moriette, G.; Chaussain, M.; Radvanyi-Bouvet, M.-F.; Walti, H.; Pajot, N.; Relier, J.P. 125

Effects of GABA and Some GABA Analogues on Respiratory Regulation in the Preterm

Rabbit

Hedner, T.; Hedner, J.; Bergman, B.; Iversen, K.; Jonason, J

Transient Respiratory Difficulty following Cesarian Delivery

Patel, D.M.; Donovan, E.F.; Keenan, W.J 146

Effects of Continuous Positive Airway Pressure on Renal Function in Prematures

Tulassay, T.; Machay, T.; Kiszel, J.; Varga, J 152

Functional Development of Adrenergic Uptake Mechanisms in the Human Fetal Heart

Saarikoski, S 158

Free Thyroid Hormone Levels during the Postnatal Period in the Pig

Nowak, G 164

Basal Insulin Secretion and Erythrocyte Insulin Binding in Preterm and Term Newborn Infants

Knip, M.; Puukka, R.; Lautala, P.; Leppilampi, M.; Puukka, M 172

C-Peptide Levels in Amniotic Fluid in Experimental Fetal Growth Retardation

De Prins, F.; Van Assche, A.; Milner, R.D.G181

Effect of Carnitine on Lipid Metabolism in the Newborn. I. Carnitine Supplementation

during Total Parenteral Nutrition in the First 48 Hours of Life

Orzali, A.; Donzelli, F.; Enzi, G.; Rubaltelli, F.F 186

Skeletal Muscle Fatty Acid Oxidation during Early Postnatal Development in the Rat

Carroll, J.E.; Shumate, J.B.; Villadiego, A.; Choksi, R.M.; Morse, D.P 191

Development of NADPH-Consuming Pathways in Heart, Brain and Liver of the Rat

Andres, A.; Satrústegui, J.; Machado, A 198

No. 5-6 Ontogenesis and Sex Differences in Rabbit Fetal Adrenal Phenylethanolamine N-

Methyl-

transferase

Padboury, J.F.; Hobel, C.J.; Gonzales, F.A.; Fisher, D.A 205

Ovarian Hilar Cells and Testicular Leydig Cells in Anencephaly

Zondek, L.H.; Zondek, T 211

Late Pregnancy Maternal and Fetal Time-Course of Plasma ACTH and Corticosterone after

Continuous Ether Inhalation by Pregnant Rats. Cytoimmunological Study of Fetal

Hypophyseal Cells

Cohen, A.; Chatelain, A.; Dupouy, J.-P 220

Evolution of Plasma Dopamine-Beta-Hydroxylase in Hypo- and Hyperthyroid Young

Rats 
Gripois, D.; Valens, M

229

Brain ß-Hydroxybutyrate Utilization in Neonatal Hypothyroidism in Rats

Crane, S.C.; Morgan, B.L.G 234

Nuclear Receptors for Thyroxine in Rat Liver during Postnatal Development in Relation to

DNA-Dependent RNA Polymerase Activity

Brtko, J.; Knopp, J 245

IV

Contents

Pancreatic Glucagon Does Not Alter Mucosal Growth and Maturation of Sucrase and Thymidine Kinase Activity in Rat Small Intestine

Buts, J.-P.; De Meyer, R.; Van Craynest, M.-P.; Maldague, P 253

Studies on Rat Hepatic Mitochondrial Hydroxymethylglutaryl-CoA Synthase during the

Perinatal Period

Caswell, A.M.; Bailey, E 263

Serum Retinol and Retinol-Binding Protein in Mothers and Infants at Delivery

Jansson, L,; Nilsson, B

Murine Neonate Hemopoiesis following in utero Total-Body Irradiation

Weinberg, S.R272

Effect of Synthetic Folic Acid Analogue, 9-Methyl-Pteroylglutamic Acid, on Fetal Chondrogenesis: Ultrastructural Observations

Schmidt, R.R.; Slobodian, S.A.; Chepenik, K.P.; Cotler, J.M 281

Effect of Lithium on Reproduction and Postnatal Growth of Mice

Mroczka, D.L.; Hoff, K.M.; Goodrich, C.A.; Baker, P.C 287

Abstracts

Abstracts from the Meeting of the Neonatal Society. Institute of Child Health, London,

February 10, $1983 \quad 297$

Announcements 303

Author Index 304

Subject Index 306

S. Karger $\cdot$ Medical and Scientific Publishers $\cdot$ Basel $\cdot$ München $\cdot$ Paris $\cdot$ London $\cdot$ New York

Tokyo $\cdot$ Sydney

Drug Dosage

The authors and the publisher have exerted every effort to ensure that drug selection and dosage set forth in this text are in accord with current recommendations and practice at the time of publication. However, in view of ongoing research, changes in government regulations, and the constant flow of information relating to drug therapy and drug reactions, the reader is urged to check the package insert for each drug for any change in indications and dosage and for added warnings and precautions. This is particularly important when the recommended agent is a new and/or infrequently employed drug.

All rights reserved.

No part of this publication may be translated into other languages, reproduced or utilized in any form or by any means, electronic or mechanical, including photocopying, recording, microcopying, or by any information storage and retrieval system, without permission in writing from the publisher or, in the case of photocopying, direct payment of a specified fee to the Copyright Clearance Center (see 'Information for Readers and Subscribers'). 
S. Karger AG, P.O. Box, CH-4009 Basel (Switzerland) Printed in Switzerland by Thür AG Offsetdruck, Pratteln 